\title{
The Review Film review
}

\section{ADDRESS FOR CORRESPONDENCE}

\section{David Blane}

General Practice and Primary Care, University of Glasgow, 1 Horselethill Road, Glasgow, G12 9LX, UK.

\section{E-mail: David.BlaneRglasgow.ac.uk}

\section{REFERENCES}

1. Blane D, Watt G. GP experience of the impact of austerity on patients and general practices in very deprived areas. Discussion Paper. Glasgow: University of Glasgow, 2012 http://uww.gla.ac.uk/media/media_232766_en .pdf (accessed 11 Jun 2012).

2. Morgan J. 'I could not look after myself, but the benefits system deemed me fit for work'. The Guardian 2012; 29 May.

http://uww.guardian.co.uk/society/2012/may/2 9/benefits-system-fit-for-

work? INTCMP=SRCH (accessed 11 Jun 2012).

3. Naysmith S. Doctors warn austerity is damaging patients' health. The Herald 2012; 15 May.

http://www.heraldscotland.com/news/health/d octors-warn-austerity-is-damaging-patientshealth.17595860 (accessed 11 Jun 2012).

4. Ipsos MORI. Doctors are most trusted profession - politicians least trusted. Trust in Professions, 2011. http://www.ipsos-

mori.com/researchpublications/researcharchi ve/2818/Doctors-are-most-trustedprofession-politicians-least-trusted.aspx (accessed 11 Jun 2012).

5. Sigerist HE. Medicine and human welfare New Haven, CT: Yale University Press, 1941.

6. Jaques H. CCG funding could be based on population age, not deprivation, says Lansley. BMJ 2012; 344: e3391.

7. Bambra CL. Clear winners and losers are created by age only NHS resource allocation. BMJ 2012; 344: e3593.

8. The Electoral Commission. Social exclusion and political engagement. Research report November 2005. London: The Electoral Commission.

http://www.electoralcommission.org.uk/ dat a/assets/pdf_file/0007/63835/Social-exclusionand-political-engagement.pdf laccessed 11 Jun 2012).

9. Dorling D. Editorial - Inequality and Injustice: some news from Britain. Urban Geography 2012; 33(4): 1-9 (in press).

10. Hart JT. Commentary. In: Watt G (ed.). General Practitioners at the Deep End: the experience and views of general practitioners working in the most severely deprived areas of Scotland. Occas Pap R Coll Gen Pract 2012; (89): i-viii, 1-40.

\section{HEADHUNTERS (HODEJEGERNE) \\ Directed by: Morten Tyldum. Written by Jo Nesbø. On UK general release}

Corporate headhunter Roger (Aksel Hennie) seems to have it all but between bankrolling his wife's gallery and paying for their lavish lifestyle, he's in a financial hole. So, indulging his addiction to danger, he moonlights as a cat burglar, stealing his clients' highly fence-able art. When his wife introduces him to the handsome, enigmatic Greve (Nikolaj Coster-Waldau), Roger thinks he's hit the jackpot but soon finds himself battling for survival against a very different kind of headhunter

Slick and blackly funny, Headhunters is a parable for our recessionary age. The neurotic Roger is not a particularly likeable hero but we root for him because we know him. He's living way beyond his means, trying to keep his head above water. To succeed in business these days it seems you have to be an amoral thief willing to do anything (including murder in Greve's case) to get ahead. Roger is almost a sacrificial lamb for us as an audience, paying for our economic sins.

\section{ADDRESS FOR CORRESPONDENCE}

\section{David Watson,}

E-mail: funny linguistahotmail.com

There's nothing particularly fresh or new about Headhunters, but it's a robust piece of high-octane filmmaking. Fast, furious, and bloody fun, see it before Hollywood pulls its teeth and produces a slick, soulless cover version

\section{David Watson,}

David is the Cinema Editor at Filmjuice.

http://www.filmjuice.com

DOI: 10.3399/bjgp12X652472

\section{Askel Hennie in Headhunters, a Magnet Release. Photo courtesy of Magnet Releasing}

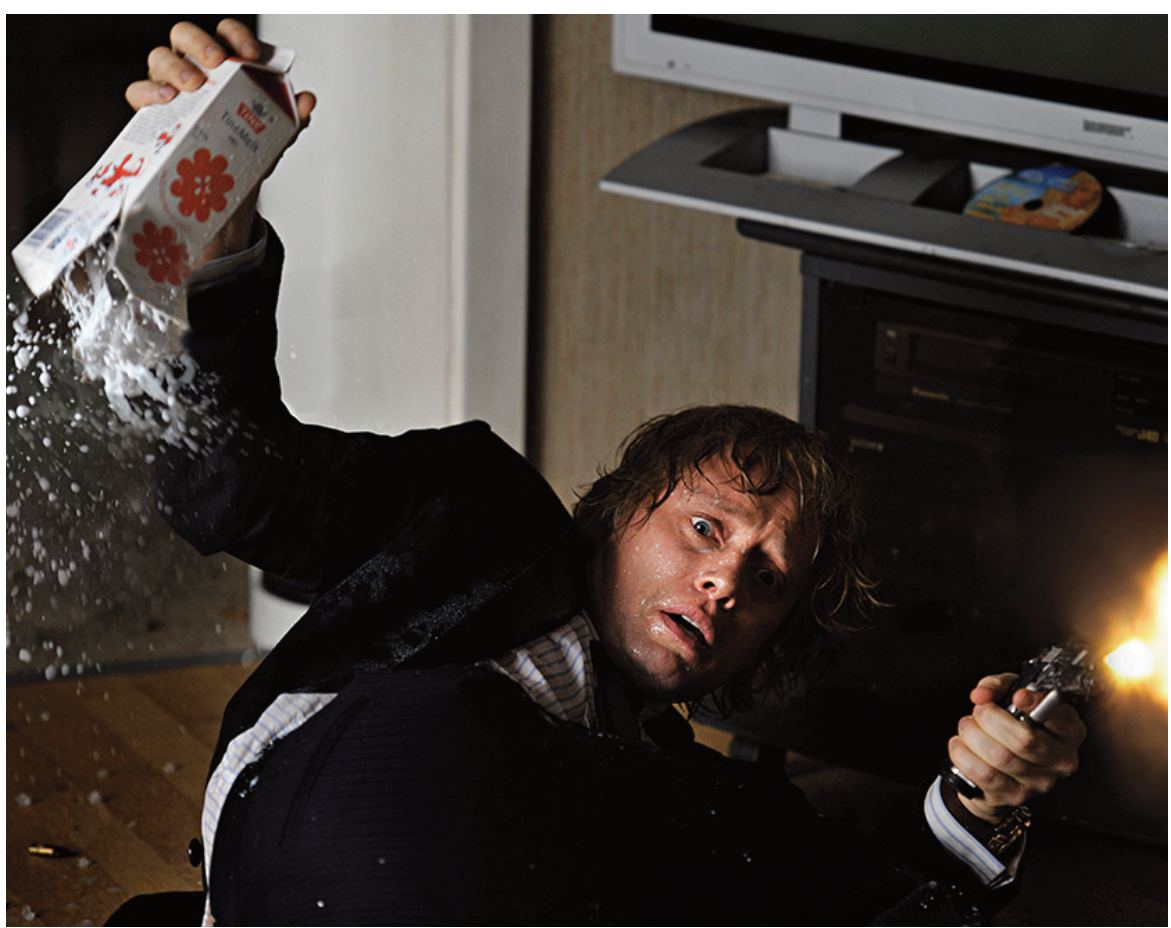

